\title{
ANTHROPOLOGICAL AND INSTITUTIONAL GROUNDS FOR REALISATION OF POLITICAL FREEDOM IN THE CONTEXT OF UKRAINIAN NATIONAL GENESIS: HISTORICAL, POLITICAL AND SOCIAL BACKGROUND
}

\section{Shypunov H. V., Prokop M.}

\section{INTRODUCTION}

The research of the essence of political freedom belongs the actual problems, which is confirmed by a number of circumstances of scientifically-epistemological, ontological, cultural and historical character. This is because human freedom is the only universal indicator of determination of condition, level of development, but most of all - effectiveness of the functioning of the whole system of social and political relations, power, actions of political institutions, different norms, legislative acts, functional acceptability of the political system, civic foundations of being. All of the mentioned aspects of freedom receive a synthesising description in that this is, probably, the most unique phenomenon, which gives grounds to the whole system of values in different historical forms of being. It is human freedom's characteristic as value that complexly defines the unity of political, economic, social, cultural and other contexts of human life.

After all, the whole history of existence of humanity is not a grandiosely rational implementation of the goals and plans of further development of state establishments, communities, systems of political power, regulatory norms of life etc., but a search for real forms of realisation of human freedom as a goal of being. Thus, the means (effective or not quite) of its achievement were states and various types and forms of power, specific social institutes, laws, norms, actions, relationships. Therefore, freedom of human action is a common factor to the above, which in historic, cultural context is exercised both through the nature of equality, i.e., in the forms of civil society, as well as in a political context as relationships, which result in political institutions and processes as a separate form of human essence, incapability, on the level of anthropological forms of being, to find means of general settlement of all parts of own life. 
Considering the foregoing, it is necessary to review the history of Ukraine in the period of the loss of Ukrainian statehood and inclusion into other states from the standpoint of political science. Since it is this example that has the potential to demonstrate political, social and ideological reasons, which have been adjacent to the attempts of achievement of political freedom of Ukrainian nation. In our view, this is exactly how the processes, which demonstrate the specificity of establishment of historic forms of political liberties in the development of Ukrainian national genesis in the context of searches of cultural, economic, social identity, are accepted. The abovementioned processes are those, which enabled the preservation of Ukrainian nation when Ukraine lost its independence and was under the rule of other nations. Because since the collapse of Kyivan Rus until the first attempts to create the Cossack state in the XVI century Ukrainian national genesis had been undergoing opposition and resistance.

Within three centuries territory of Kyivan Rus had transformed into the arena of a non-stop battle of the states for its colonisation under the protectorate of Roman Catholic Church, supreme rules of which were thinking in an empire scale. The Ottoman Empire had been constantly threatening from the south. Its pressure on the Western world had resulted in the creation of Habsburg monarchic empire. In the East, there had been a constant threat from the Tatar hordes. The Moscow state was objectively interested in the territories of Kyivan Rus being released from the custody of the Lithuanian kingdom, and that the Cossack state became a fort post on the borders with the Ottoman Empire and Poland. The latter had been preventing Russia from its expansion into the west. In this period, which we call the time of formation of universalist expansionist state-empires, the Cossack state emerged and developed, having inherited the best spiritual and political values of Kyivan Rus, Kingdom of Galicia-Volhynia and substantially developed them, thereby enriching Ukrainian national life. Thanks to the Cossack movement, almost a centurial destruction of the liberties of the Rus humanity had stopped. The defining tendency of the national liberation movement of the Cossacks, its territorial, economic, military and political self-organisation arises as one of the forms of a qualitatively new Ukrainian nation. Typical characteristics of the Cossack movement - direction on settling free lands of the Dnipro 
banks and production of material goods, which gives grounds to a free and prosperous life.

Studying political freedoms in the modern Ukrainian national genesis and analysing political institutions, which secure them, we need to pay attention to the objective and subjective factors, which cause the formation and functioning of those institutions, the culmination of their development, and decline. We need to assess relevant forms of the national political culture, which along with other factors determine the appearance of the historic forms of political freedoms.

\section{Modern Aspects of Formation of Political Freedoms in Ukraine}

In the period of first wars against Poland, the carriers of the sovereign tendencies and leaders in Ukraine's fight for independence were the representatives of old Ukrainian aristocracy. Amongst the social groups in Rus were also those, who carried "military and boyar service" and were relatively free, others were serving "their duties before the state by negligible contributions, honey, leather" ${ }^{\text {. The state }}$ was distributing land to the elders and people of the higher social groups, particularly those who accepted Catholicism. In the Rus community political subjectivisms had grouped into two main types. The first one was characterised by the tendency that Rus community must be orthodox and free. In this context "Rus had opposed itself to Poland as representative of another spiritual culture, not only unable to disregard itself in favour of another, but demanded a corresponding respect to itself, - emphasises O. Yefymenko. - Latin Christianity had confronted Greek Christianity on our territory. There was also an attempt to make peace between the two historically hostile religious and cultural foundations, however, it only sped up the horrendous social catastrophe, which victim was the Southern Rus" 2 . However, the essence of the transformation process of the normative legal system of Rus lands within Poland was actually directed to make the integrated community forget, erase out of the historic memory the knowledge and belonging to other nation. Rapid growth of the number of people dissatisfied by the politics run by the ruling class complicated the

\footnotetext{
${ }^{1}$ Ефименко А. История украинского народа. Київ: Либідь, 1990. С. 170.

${ }^{2}$ Ефименко А. История украинского народа. Київ: Либідь, 1990. С. 178.
} 
political situation, which was also caused by the fact that part of the Rus elite was consciously serving the Polish state, having obtained noble status.

We should stress that both theoretically and practically our research of the political freedoms in Ukrainian national genesis aims to clarify how the political subject is reconstructing within the social and political transformations of Rus as parts of Poland, as well as under the influence of geopolitical aspects. Rus landlord elite had been suffering a kind of political discomfort, even dissatisfaction, since it had a relatively low impact on the policy of Poland state with regard to Rus lands and their inhabitants; this elite had realised they were themselves limited in the rights and political freedoms.

One of the reactions to the abovementioned and one of the forms of the essence and being of orientation of social groups or Rus lands, which were bordering the Moscow kingdom yet were not a part of Poland, were political orientations to obtain help from Moscow. Thus, the analysis of the political freedoms during the time of the ruling of Rzeczpospolita must be supplemented by the influence of the Moscow Orthodox Church of the Moscow kingdom on the formation of political subjectivity of the part of Rus elite. We also note that Rus political elite on the territories bordering the Moscow kingdom was hoping that the orthodox religion of this state would help procure freedoms in case of separation of the part of Rus territories from Poland and their annexation to Muscovy.

It was the pro-Muscovite military men of the Rus lands who became an active force amongst the Cossack masses, who served the Moscow tsar. "Cossacks took allowance from the Moscow tsar, notes O. Yefymenko, - for the protection of his domain from the Tatars and considered themselves free to go across the Don, when the state oppressed them on the Dnipro" 3 . Therefore, we can understand the registered Cossacks, who served to Rzeczpospolita, Cossack structures, who drifted in their political sympathy to Moscow tsar, and to determine the principle Cossack structure, which had a clearly identified Rus national patriotic and subjective foundations to disregard both the Polish state and the Moscow one.

${ }^{3}$ Ефименко А. История украинского народа. Київ: Либідь, 1990. С. 194. 
While we are on the subject we should also note that the Polish police regarding Rus nation was aimed not at the development of selfgovernance, improvement of the rights and freedoms of various social groups, but on the maximum exploitation of the natural and people resources for strengthening of their its own geopolitical status and forming the largest Polish aristocratic elite. In this context a special attention should be given to the legislative acts governing domestic and foreign trade. "Polish government, - notes N. PolonskaVasylenko, - tried to monopolise Ukrainian foreign trade in the hands of Poles and direct it to Krakow, Lublin, Sandomyr and other Polish cities..." Kazimierz issued a privilege to Krakow traders, which ensured their monopoly right to goods, thereby forcing Wroclaw and German traders to buy Ukrainian goods only via Polish traders... Consequently to certain obstacles, high custom duty, transport complications, Ukrainian trade is declining" "4. Therefore, Polish government restrains the freedom of trade by Ukrainians and guaranteed freedom of trade to Poles, providing them with a secure legal protection.

As a result of the aforementioned factors, a lot of Rus population psychologically adapted to the political and cultural centre of Kyiv, were standing out by their worldview of the situation. Partially, we may explain this by a relatively high amount of the representatives of free-loving city and village population in the social structure. Significant amount of population, who settled the southern Dnipro banks, "continued the uninterrupted tradition of the Rus life since the prehistoric times, for the development of which two things were necessary - forest and water...In this aspect, Ukraine was a perfect country, a swimming honey and milk"5. Actually, on the territory of Dnipro and Buh embankments general tendency to replicate social, economic, communal and political life for the majority of the population was replicated in the new attitude to the Polish policy, was characterised by the spread of freedoms and political self-governance, as well as ignoring of the power of Polish bureaucrats. No further threat on "his freedom, work or property was not possible, since,

${ }^{4}$ Полонська-Василенко Н. Історія України: у 2 т. Київ: Либідь, 1995. Т. 1. C. 371-372.

${ }^{5}$ Полонська-Василенко Н. Історія України: у 2 т. Київ: Либідь, 1995. Т. 1. C. $166-167$. 
based on the words of masters, it knows pretty well what way to take to run away"6. Consequently, the Cossacks became a social and political self-organised force within the Rus lands under the jurisdiction of the Rzeczpospolita, which played a dominant role in formation of new historic forms of political rights and freedoms in creation of nation.

Of course, existence and freedom on Zaporizhzhya are inseparable. However, the Cossacks themselves had reached a bifurcation point in their attitude to freedom. In terms of modern sociology, this attitude may be defined as freedom for something and freedom from something. Social conditions and community upbringing did not allow the lower Cossacks to fully realise their potential to freedom, be free from the most burdensome obligations of the feudalism - master, state administrator and tax collector. It looked like Zaporizhzhya fell out of its surroundings. A rather early for its time free-loving maturity of the Cossacks was somewhat outrunning the social and psychological capability to positively use freedom.

We draw your attention to the undisputed fact that the Cossacks had revived a military organisation of the Kyivan Rus (a division by a thousand), as well as viche structure. Self-organisation of the Cossack society at the earlier stages of formation divided into parts, which were governed by the elected colonels (in Kyivan Rus - thousanders, tysyachnyky in Ukrainian) with the platoons of hundreds with the elected commanders (sotnyky in Ukrainian). The whole of the Lower army was led by the elected hetman.

Our preliminary conclusion is important, since the institutions of power of Kyivan Rus did not disappear from the structure of Ukrainian national genesis. Thus, the historic process of development of state institutions from Kyivan Rus to Cossack state was uninterrupted. Social and political transformations in the national formation of the Kyivan Rus as a result of the changes in priorities of values in the domestic lives of Rus-Ukrainian preserve and develop political rights and freedoms.

Ukrainian Cossacks started their political career as a chaotic politically protesting mass of deserters from the Polish state, which had been deliberating the nation of Kyivan Rus. "Situation of

${ }^{6}$ Ефименко А. История украинского народа. Київ: Либідь, 1990.С. 171. 
Ukrainians in Poland was especially harsh, - notes V. Soldatenko. There, a terrible national and religious oppression was cultivated: unbearable pressure on the orthodox church and religion, pushing of Catholicism by all means possible, increase of obstacles in the development of national culture, language, education etc." Therefore, the Cossacks had become the initiators of revival of the idea of Ukrainian statehood, having inherited it from the prince-ruled Rus and further forming it in a desire to liberate from the foreign oppression.

M. Popovych considers Cossacks as a military and political support for the colonization by the villagers of the unsettled lands, later - they became the guarantor of the protection of villagers and orthodox religion from the Polish aristocracy ${ }^{8}$. Cossack community had limited, to the extent possible, the expansion of Poles, Crimean Tatars and Muscovites to the Ukrainian territories, which were in their turn threatened by enemy states. With the inception of the Cossacks social and political self-organisation of the cities and villages was conducted using the Kyivan Rus self-governance examples, such as viche. "Thus, the protectors of the southern borderline and desertersindustrialists, - emphasizes V. Shcherbak - who were in constant contacts with the Tatar nomads, are first reminded of in the sources of the second half of XV century under the name of "Cossacks". M. Hruskevskyi had the opinion that at first "Cossacks were protecting only their Cossack rights and privileges of the local villagers standing behind them. Now, they are becoming the defenders of the whole Ukrainian, or, as they used to say it back then - Rus nation" $"$.

Genesis and development of the Cossack political factor at the same time presupposed the change in the social political consciousness. The feeling of the national incompleteness produced a strong reflection of own self-consciousness within the Rus population under the Polish rule. This act of thinking had risen the everyday

${ }^{7}$ Солдатенко В. Революції в історичній долі України. Віче. 1999. № 4. C. 118.

${ }^{8}$ Попович М. Нарис історії культури України. Київ АртЕк, 1998. С. 159.

9 Щербак В. Українське козацтво: формування соціального стану. Друга половина XV - середина XVII ст. Київ: КМ Academia, 2000. С. 35.

${ }^{10}$ Грушевський М. Історія України. Київ: Либідь, 1992. С. 109. 
consciousness to the level of own political identity and formed a political motivation to fight for own national dignity and restoration of the political freedoms, which Poland had deprived them of. The appearance of the embryos of the national-patriotic and national liberation desire initiates the will for political unity of all social groups of one nation. Through comparing political status of Polish and Rus people we can understand the political inequality and self-recognition of the national non-freedom.

We should also note that the decisive characteristic of the Cossack activity became the various types of personal aims with the dominant role of the idea of free life, liberated from the impact of foreign states and oppression from the masters. By their substance they are similar to the strategy of achieving political freedoms with the sub context of preserving the Kyivan Rus "freedoms" obtained earlier with Lithuanian and Rus states. However, the Cossack ambitions stand out from the then-massive protest movements, which were followed by a motivation of vengeance for abuse from the Polish masters, by the fact that the decisive motivation of their military and defensive activity was a "point of view, which recognised a complete freedom of political behaviour for the free Cossack militants"11. The development of the Cossack movement proves that the motivational resource of the political freedom was more powerful than other subjective resources.

It is important to note that at the first stage of the establishment of Cossacks there were three groups of the Kyivan Rus population: 1) "Cossack camps" in the deltas of Ros and Sula, which remained from the XI - XII centuries and resided there mixing with the Turk inhabitants; 2) successors of the Kyivan Rus nation, who settled as a result of the military expedition of the king Vitautas into the steppe; 3 ) deserters from the territory, which was included into Rzeczpospolita $^{12}$. In this manner, territorial economic and cultural settlements were formed, thereby reiving the social and political structure of the territorial communities and self-governance on the basis of "freedoms". At first, the Cossacks were not distinctive by their military skill: it was not on top of the list, but merely a way to

${ }^{11}$ Грушевський М. Історія України. Київ: Либідь, 1992. С. 194.

12 Щербак В. Українське козацтво: формування соціального стану. Друга половина XV - середина XVII ст. Київ: КМ Academia, 2000. С. 48-53. 
protect own household and rights of the population. With the appearance of the external military forces, which claimed the free Cossack settlements, the military and political structure was formed, and the functions of protection of territory were assigned to the professional warriors. It was a first step to the unity of the three different Kyivan Rus social groups.

There were a lot of regional settlements with their own selfgovernance bodies at the abovementioned stage. The Tatar claims caused the formation of Cossack troops of the Lower Dnipro embankments. Simultaneously with the increase of the Polish pressure the number of deserted was increasing, and the Cossack troops were organising for self-defence from the masters. In all of the groups amongst the displaced the Kyivan Rus national consciousness was dominating with the typical ideas of priority of free life of the community and strong desire of social justice ${ }^{13}$. For all social groups, which formed the Cossack nation, the most important was own social, political, economic and cultural tradition, appreciation of the freedoms and civic duties, which was defined by the actual social practice. The presence of Kyivan Rus values in the lives of the first Cossack settlers made them capable of unification and realisation of the new forms of national existence. When we refer to the classics of political philosophy, who formed the liberal ideology, we would note that the Cossack self-organisation is fully corresponding with the concept of "social creation" of J. Locke. "Political societies, - he wrote, commenced with the community organised out of free will and mutual agreement of the people, who acted freely while choosing their rulers and forms of governance" ${ }^{\prime 14}$. The fact that the Cossacks were a social and political self-organisation and heir to the Kyivan Rus nation is proven by the regulation of the Seim, which stipulates: "People of the southern Dnipro banks and other people, who voluntarily organised themselves, are considered enemies and traitors of Poland" 15 .

From all we have said before, we may derive that the birth of the Cossack state and specificity of the national genesis first and foremost

13 Яковенко Н. До питання про методологію вивчення історії України. Генеза: Філософія. Історія. Політологія. № 1 (4). 1996. С. 119.

14 Локк Дж. Два трактата о правлении. Сочинения: в 3 т. Т. 3. / Локк Дж. Москва: Мысль, 1988. С. 183.

${ }^{15}$ Сфименко О. Історія України та її народу. Київ: Мистецтво, 1992. С. 200. 
lies within the political content of the forms of communal life and internal stimuli through which the spiritual activity of the contentcreating motives comes to light. Historians defined that behind the substantial stimuli of the formation of the Cossack structure was the free family household, democracy in social and political life and national beliefs in spiritual life, which was a component of the contextual creation of the new Cossack state. Based on the fixed ethnic attributes of the Lower Dnipro embankment social, economic, cultural, military, and political self-identification ensured its integration. Settlements on the free lands without any governance from above "filled into correct forms of being, elected military, civil and judicial administration from its own environment (colonels, sotnyks, otamans, judges etc.), managed to protect its own new lands" ${ }^{\prime 16}$. From the very first years of the existing of Cossacks movement national and patriotic spirit had not encompassed only memories of the past, but had also been creating a moral creed, pursuant to which the Cossacks evaluated their political role in the fight for the national freedom and Christianity.

Among the Cossacks the psychological cooperation and connection of the political principles of self-organisation of free lifestyle in the Lower Dnipro embankment are seen especially clear; common characteristics of the lifestyle, which may be followed back to the pre-Kyivan Rus times and stipulated within the state of the Kingdom of Galicia and Volhynia. This connection has primarily material and spiritual nature. When the deserters and free people settled on the untouched lands of the former Kyivan Rus, they reconstructed social and political structure of life in all its forms, based on the achievements in the household, social, political, spiritual activity, which traditionally passed along from the predecessors.

Moreover, one of the peculiarities of the Ukrainian national genesis in the XV - XVIII centuries is the return of the territories of the former Kyivan Rus under the state protection of the Cossacks, enrichment of the social, economic and cultural life with a national content, reproduction of the social, political and spiritual integrity of the nation. The dominant political factor of the national genesis of the Cossack age was the reservation of the Ukrainian territory and its

16 Яворницький Д. Історія запорізьких козаків: у 3 т. Т. 3. Київ: Наукова думка,1992. С. 13. 
transition into a special protection of the state. To the Cossacks, ethnical territory of the Kyivan Rus was something of a political, social, economic and spiritual reservation, where historically inherited values as an inseparable component of the dynamic survival have been protected and developed.

Also, establishment of the companion cooperation and brotherly mutual support is also one of the most important examples of the social and political similarity of the Cossack humanity. The main social and political principles of the "Cossack structure" were rejection of the feudal dependence and class inequality, equality in the right to own land and agricultural fields, right to craftsmanship and trade, unlimited access to the Cossack society regardless of the class or nationality. As regards the spiritual and political spheres not directly related to the welfare of standalone families-households, they had been developing depending on the special gifts, skills, talents, wit, military bravery and nobleness. Within the Cossack environment existed several moral norms: the first place was taken by the family comfort and family welfare; for their protection, the Cossacks had created military troops and established the respective political construction.

Overall, the creation of the Cossack community may be evaluated on different levels depending on its significance to the Ukrainian national genesis. On the political level, the Cossack protest movement had an ideological creed: indefeasible right to free life with civil selfgovernance and spiritual consciousness, which is inseparably connected with the orthodox religion. The requirements of the Cossacks are simple and comprehensive: Ukrainian nature, where the ancestors had lived since the beginning of time, had sufficient resources for the free economy. The Cossacks desire to maintain traditional social and political equality for all people before the law and their participation in the life of the society. The Cossack community, as a group of the free families and households, desired to affirm the spirit of the national solidarity and fraternity among the societies and groups.

We should additionally note that the first stage of the establishment of the Cossack movement was outstanding by an intensive development of the democratic society, which had the characteristics of the civil society, and traditional institutionalised 
norms were examples of the law. "Everyone who arrived to the Cossack lands, was considered as free man and obtained the right to use agricultural fields equally with everyone else and participate in self-governance, including in the election of the alderman. At the same time, everyone was obliged to take weapons to protect the population" $"$.

In the Cossack society labour, political, military, social and household activity was performed in various forms, which were determined by the substance and structure of the social needs. This means that the principal constructive work on the creation of the Cossack nation was performed by the peasants and the burghers, among which - blacksmiths, bonders, furriers, tinsmiths, weavers, tailors, traders etc. The first territorial settlements of the Cossacks had all characteristics of democracy, in particular in the social, economic, political and cultural spheres. Therefore, in order to protect this structure armed and professionally trained troops were necessary. Military and political organisation of the Cossacks was subordinated to serve territorial and civil society, free from the state and the masters.

Contrary to the Polish-Lithuanian state, Ukrainian ethnos, particularly, its active and conscious part, had designed a perspective corresponding to the ethnic standards and was not afraid to lose the national identity by initiating active search of free land for reconstruction of its own being. D. Iavornytskyi pays attention exactly to this very aspect of the Cossacks: "Zaporizhzhya, with its society, elections of the aldermen, unified treasury, common for aldermen and simple Cossacks food, separate camps - all of the above are the same orders of the civil society and viche of the life in southern Rus, but only at the highest level of development"18.

The Cossacks were necessary for the establishment of the political freedoms, since because of them at least four fundamental Ukrainian political institutionalised imperatives revived and developed: 1) democracy; 2) universality of the free family household; 3) organised spiritual space based on the national faith; 4) joint land ownership with the family households. Social and political civil

${ }^{17}$ Голобуцький В. Запорозьке козацтво. Київ: Вища школа, 1994. С. 108.

18 Яворницький Д. Історія запорізьких козаків: у 3 т. Т. 2. Київ: Наукова думка, 1992. С. 13. 
mechanism of organisation of the law enforcement also deserves attention.

It is important to note that the political self-organisation was performed by the masses, who almost did not have any national elite due its majority being polonised. Thus, at the beginning the Cossack settlements hide within themselves "a mystery of the unknown and provide food for different assumptions and considerations"19. For the Cossack national genesis, the need for the elite was crucial. Such elite formed from the small number of Ukrainians, who managed to preserve their Ukrainian identity within Poland. Later, the Cossacks had delegated many of their leaders from their ranks, who became a nation-creating elite. It revealed substantial organisational, political and military skills, national patriotism, loyalty to the people and its spiritual values. "If these people have their own state, it must have not only a creative elite, but also a state elite" 20.

We must conclude, that formation of the Cossack nation has not only quantitative, but qualitative metrics as well. According to this, we should clarify the stages of its establishment, formation and development. A fundamental component of nation is its leading class, which provides cultural, linguistic and political integration of all social groups. Integration of social groups is based on the spiritual and state-building solidarity, due to which the foundation of the national genesis is formed. In the period when the Polish state, into which the lands of the Kyivan Rus transitioned, the political elite and Roman Catholic hierarchs went into offensive and started destruction of the Rus nation, using various pressure and oppression mechanisms; it was the process of decline of all spheres of the Rus national life. The population of the Kyivan Rus territory during XV - XVI centuries "had most often named itself collectively as "Rus"21. This selflabelling became a fundamental component in the national selfacknowledgement when the Kyivan Rus society went into crisis, and played an important role in unifying and igniting the masses to the

19 Яворницький Д. Історія запорізьких козаків: у 3 т. Т. 3. Київ: Наукова думка, 1992. С. 15.

20 Блажейовський Д. Берестейська унія та українська історична доля $\mathrm{i}$ недоля. Т. 1: Внутрішня вартість медалі. Львів: Каменяр, 1995. С. 44.

${ }^{21}$ Яковенко Н. Нарис історії України з найдавніших часів до кінця XVIII ст. Київ: Генеза, 1997. С. 174. 
protest actions against the politics of the Polish state. At the beginning the political protest of the Rus nation against the Polish centre was subject to typical religious arguments. This means that in the national self-consciousness of Rus people a traditional psycho-behavioural architecture existed, and such architecture could not have been forged into Polish statehood, serfdom and Roman Catholic faith.

At the level of the national and worldwide orientation of the Rus people the already formed Cossack groups were not so differentiated among themselves, but rather developed in the direction of increasing common adaptive capability to restore a brand-new nation. Within the conditions of the social and political integration, adaptation of the Cossack military, political and economic groups, manufacturing structures, territorial administrative bodies, cultural and education institutions are being established. During this period lower and city Cossacks differentiated. In the environment of the lower Cossacks with the centre in Zaporizhzhya Sich the permanent democratic revolution prevailed. It somehow made this community distant from the city Cossacks. The latter were involved with the Polish political system and stood out as specifically free social joint community. Further development of the Cossack community continued under the aegis of strengthening of military, political, cultural and economic ties. Preserving the common orientation for the creation of nation, urban and lower Cossacks considered themselves as part of the single cultural and linguistic territorial community, which lifecycle must be regulated and corrected by own power means without the involvement of the Poland, Moscow, Turkey. This phase of the national genesis of the Cossacks is tightly connected with the military, political, social and economic pluralism, discussions between the leaders of the urban and lower Cossacks, compromises in the processes of national creation. Sometimes, sharp disagreements had been revealed in the approaches of the lower and urban Cossacks on the future of the people and the state.

Therefore, the Cossacks were by all means a self-sustainable nation, with existing institutes of state power and state territory, national culture and language. Frankly speaking, with the beginning of its existence the creative potential for restoration and development of the Kyivan Rus actively revealed. Another logical conclusion is that the structure of a more or less completed and ideal military and 
political state management reflects the unity and structure of the social process in the Ukrainian national genesis. At the same time, an individual in the Cossack society arises as a social Cossack "I", which makes him a source of movement and development of the society.

Another important thing to emphasize is that in the historic competition for the national originality Ukrainian people had actively demonstrated their dissent to live in the political feudal dependence from the Polish and Lithuanian landowners. This is a stable political indicator of the ethnic - and, at the same time - political delineation. Only in the juxtaposition o own nation to another the people of Kyivan Rus were a single unit, with a strong patriotic colouring. The Cossacks are described as a community with an inherent division of labour, which is based on the national tradition, behaviour, determined by the jointly determined rules. Moreover, there is a comprehensive understanding of the economic, military and political actions of one social groups with another. There is no simple homogeneity of actions, but rather a social and political unity, where the actions of the separate groups are based on the mutual agreement.

\section{State and Nation Creating Factors of Institutionalising of the Political Freedom in Ukraine}

Ukrainian national genesis does not represent an absolutely uniform road to progress in the political history. Maybe, this is the foundation of the contradiction, which causes either the decline of the national life and restriction of political freedoms of the national masses, or a stormy uprising of the national and patriotic feelings and mass awakening of the national self-consciousness and fight for political freedoms. Assessing the historical changes in the social and political lives of the nations, A. Whitehead mentioned: "New eras emerge relatively suddenly, and we only understand that when we pay attention to the barriers, which divide the millennia of the whole previous history. Isolated nations suddenly fight their place in the main current of events..."22. Mid-XIX century became a period of national restoration for European nations. This was preceded by the substantial social and political events of the XVII - XVIII centuries,

${ }^{22}$ Уайтхед А. Избранные работы по философии. Москва: Прогресс, 1990. C. 56. 
in particular, bourgeois and democratic revolutions, which brought to life ides of freedom, equality and justice significantly. That is because the concept of political freedom for nations, which were conquered by the empire states, had emerged as a scientific philosophical and political thought in the first half of XVIII century already in the works of J. Locke, G. Vico, A.R.J. Turgot, N. de Condorset, I. Kant, G.W.F. Hegel and many other thinkers and gain general civilisational worldview meaning.

Demonstrating the abovementioned, we have to refer to the work "Basics of the science of the general nature of nations". G. Vico was first in the history of the social and political thinking to describe the genesis of the humanity through the basis of the philosophical and anthropological reflection. He sees "the general nature of nations and formulates eternal laws of the perfect history: all nations derive from their inception to the highest peak of incline, after which the way to decline begins" 23 . The scientist aims both theoretically - since his subject of research is "general nature of nations" - and scientifically (historically) to determine the nations' way to maturity, taking into consideration three types of social and cultural time: 1) religious; 2) heroic; 3) civil. The main idea of the thinker about the social and cultural component of nations found its followers amongst the representatives of the philosophic group, who took "social and cultural dynamics" as their fundamental views on the issue of political freedoms and national genesis.

The historicism in the research of lives of nations had helped G. Vico to develop the most adequate view on the periods of the development of the national culture of his time and to make social and political thinking closer to the complex understanding and interpretation of the arts, religion, morale, law and forms of social and political self-organisations, economic life in their unity and mutual dependency. According to the R. Collingwood, G. Vico sees the historic process as a process through which human beings build up systems of languages, customs, laws, governance etc.; in other words, he thinks about the history as of the history of the genesis and development of humanity and its institutions.

23 Булатова Ю. Про поняття філософії історії. Вісник Київського університету. 1996. Вип. 25. С. 5. 
Additionally, G. Vico is also the owner of an important thesis: the social and political thought in the study of the genesis of nations must be both specific and historic, and constructive, and critical. The latter refers to the fact that in the views on the history of a specific nation, particularly on the political construct, there are imprints, distorted by the ideologists of the empire states. The thinker cautions the researchers and emphasises on the necessity of bringing the completely forgotten truth back on the basis of a scientific analysis. I our view, the concept of political freedoms in Ukrainian national genesis lacks historic truth and completeness according to the needs of modern development of the nation. Russian political science and historiography, directed on the interest of the empire, reorients Ukrainian national genesis, political freedoms in the context of Russian political system and empire spirit. If in the light of the abovementioned and from the standpoint of objectivity of political process of the establishment of the modern Ukrainian nation in the Russian historiography and political science we search for the ideas, which make our history closer to the Moscow grand state one, we may derive the myths, aimed at overcoming of the distance of the Ukrainian people from the orbit of political interests of Russia.

Contrary to the aforementioned, representatives of the social and political thinking managed to develop a new method of using sources - a method of critical reflection, which had two components: firstly, the analysis of the sources (literature, word-of-mouth and chronicles); secondly, internal critics from the moments, which contradict one another. This method became a safe logical achievement of the mid-XIX century for the historians, philosophers, literature critics etc. Let's say, J. Bachynskyi, considering in line in the spirit of the European Enlightenment, developed a theoretical model of the collapse of empires, including Austrian and Russian, which were ruling Ukrainian territories at the time. He claimed: "The classic form of the modern production is a great capitalistic trade, which is represented by the bourgeoisie. The classic form of the capitalistic, bourgeois state is a national state" ${ }^{, 24}$. The scientist developed a conceptual scheme of formation of the bourgeois and democratic states national-based stated, applying undisputed

24 Бачинський Ю. Економічні підстави самостійності націй. Київ: Смолоскип, 2006. С. 420. 
consequences of the social and political events in Europe and America, caused by two movements - industrial bourgeoisie and demolition of the monarchic empire states, as well as the national liberation movement, which was headed by the national patriotic intelligence.

Specifically in the period of strengthening of the economic potential of the bourgeoisie of the European countries, acknowledgement of the ideas of classic liberalism the history of the collapse of Austria and other national states, projected by J. Bachynskyi, started to form. The reign of capitalism in Austria had expedited this process. From the time, when capitalism became the leader in Austria, and the economic welfare of separate regions was tightly connected with their political anatomy, the expedience of the Austrian existence was decreasing day by day. Generally speaking, removal of Hungary from the Austrian political body was the first indicator of Austrian collapse; the true revelation was the "state rights" of separate Austrian nations in Halychyna (Galicia) - frequent references of the Halychyna bourgeoisie about its autonomy.

The novelty of the J. Bachynkyi's ideas on the bourgeois and democratic character of the modern national genesis lied in the fact that he gave Austrian state an advantage in its capability to provide better political and legal conditions for the national restoration of the peoples, particularly, Ukrainian, over Russia. He was certain that Austria had a political support of other states and nations, which would rather be under Austrian rule than under Russian. According to J. Bachynskyi, the formation of the bourgeois and democratic Russia would expedite the process of Austrian collapse. Russian monarchy will "fall" under the influence of the capitalistic economy, and afterwards "the peoples will declare their claims of independent political freedom, the question of legitimate state for Ukraine will also emerge. The question is brought to the agenda by the force of the facts not so by its formal and national nature as, for instance, the sense of the national sovereignty and cutting-off language... but rather a force of facts of the economic and administrative nature" ${ }^{25}$. Therefore, in the social and political thinking of the Ukrainian national intellectual elite we may see a clear tendency of the political development of

25 Бачинський Ю. Економічні підстави самостійності націй. Київ: Смолоскип, 2006. С. 140. 
empires, which must "fall" under the influence of the bourgeois and democratic ideology. It is a big merit of J. Bachynskyi that he had seen a solution to the problem of political future of Ukrainian nation in the nearest historic perspective due to the collapse of the Russian and Austrian empires. Ukrainian nation in the mid-XIX century started to successfully develop self-sustainable cultural and enlightening organisations, and further improved the political organisations, thereby jointly awakening the national selfconsciousness.

Analysing the rhythm of the political life of Austria and Russia, Ukrainian and Polish nations, J. Bachynskyi, using the historic view on the relations between the Polish and Ukrainian states, was clear when he stated the following: "Political sovereignty of Ukraine not only from Poland, but from the "Great Rus" is hardly complicated due to the fact that both are depleting natural resources for themselves...therefore, the position that Ukraine will place against Poland, must be similar to the position that it must take against the "Great Rus"...from both of these nations Ukraine would be forced to fight for political sovereignty, political independence" 26 . This concept was suitable for the second period of the XIX-early XX century. The brightest national liberation movement in Russia and Austria, which clearly understood its political history and acknowledged its mission, was Polish. The process of national genesis throughout all this time was correlated with the realisation of history and process of fighting for the true political freedom - national sovereignty.

As an example to the abovementioned, we must analyse the general trend of the Ukrainian national genesis of Galician Ukrainians in Austria. Let us stipulate: Austria obtained control over Halychyna (Galicia) after the First division of Poland in 1772. "The population of the region was in a complete oppression...national masses were enslaved and could not have demonstrated any spirituality, Ukrainian city residents were low-numbered, rightless and powerless... additionally, the orthodox religion was close to Catholicism", says O. Iefymenko.

Let us take a look on the changes, which occurred in the social and political life of Ukrainians in Halychyna under Austrian rule. "All

26 Бачинський Ю. Економічні підстави самостійності націй. Київ: Смолоскип, 2006. С. 144. 
of the activity of Joseph II in its general tendency, - according to the conclusion of O. Yefymenko, - is generally favourable to the uprising of the Ukrainian population from the oppression it had suffered back in that time" 27 . At the times, the social, cultural and political atmosphere, which was beneficial for the development of the education of all nations, restoration of their spiritual culture was dominating in Austria. Such tendency to the general upbringing of education of all social groups was unfamiliar to the rest of the worlds. Joseph II, "trying to liberate the peasants from the serfdom dependency..., issued several orders, which had substantially improved the conditions of the Ukrainian peasantry in Halychyna; introduction of the inventories had limited the bondhold, as well as general arbitrariness of landlords to serfs; the peasants were liberated from the dominion (owner) justice and was subject to the general state jurisdiction; the people masses were returned certain personal rights, such as the right to marriage without the knowledge of the landlord, right to inheritance and intestacy by will, right to join city cooperation and craft shops, right to apply to higher educational institutions equally with the representatives of other social groups" ${ }^{32}$.

As a result, we must conclude that the progressively oriented representatives of the Ukrainian intelligence of Halychyna were conscious of the fact that the Austrian government had provided them with the legitimate rights to restore Ukrainian language, writing, history, knowledge of the national traditions, songs, customs etc. Thus, they arrive to the conclusion: the basis for the social, political and cultural progress is an institutionalised educational system. In the educational activity the intelligence of Halychyna saw once of the sources of reviving Ukrainian self-consciousness. According to the understanding of "Ruska Triitsya" ("Rus Trinity") one of the preconditions of revival of the Ukrainian nation was a duty to development and spread of the education in the native language. Many students and clergy of the Uniate church, persuaded in the necessity to revive the native language of the Ukrainian society, provide it with the same rights, which the Poles, Hungarians, Czechs had, joined around the "Ruska Triitsya" ("Rus Trinity").

\footnotetext{
${ }^{27}$ Єфименко О. Історія України та її народу. Київ: Мистецтво, 1992. С. 391.

${ }^{28}$ Сфименко О. Історія України та її народу. Київ: Мистецтво, 1992. С. 391.
} 
Therefore, Ukrainian national political ideology in the Eastern Halychyna began to form in the context of the European national liberation movement and under a significant influence of the ideologists of Italian, Czech, Polish, German nationalism. As to the characteristic of this option of the national liberation movement, its most decisive feature would be philosophic and political ideas of liberty, equality and justice of the classic liberalism, particularly, of the ideologists of European nationalism of the mid-XIX century.

\section{CONCLUSIONS}

The performed analysis allows us to conclude that the formation of the political freedoms in the history of Ukraine, since the beginning of time and until today, had undergone several stages. The basis for such changes, which determined the specificity of the progress of freedom and obtaining by such freedom of political colours, in our view, constituted, firstly: the condition of the development of selfconsciousness of the group at the early stages, later - selfconsciousness of the individual and an acknowledged distancing from other groups and persons (a slow historic exit beyond the patriarchal paradigm "our own - stranger"). Secondly, the recognition (acknowledgment) of oneself as a member of certain group, which ceases to have indications of a family, of a genealogy. Thirdly, the recognised distinction between the ruler, king, and those, who he is ruling beyond the family ties, which in its turn determines the recognition of the legitimate power not granted by God, genealogy, family traditions, but rather formed as a result of agreed rules and defined legal rights. The aforementioned rules and rights form the system and normative requirements, which are different from the traditions and natural limitations. These are the factors which, although not yet actually pointing at freedom, limits and dynamics of increase, became those determinants and conditions that have actually caused quality changes in the practical firms of freedom and means of its consideration.

The study of political freedoms in the Ukrainian national genesis of the princely days allows us to conclude the following: first of all, Kyivan Rus population was clear in understanding their connection with the former social and political structure, which had traditionally secured historically formed political freedoms, which provided for a 
real opportunity for self-governance; secondly, they had been carefully protecting the historic memory of Kyiv as a political and spiritual centre of the Rus territories; thirdly, Kyiv had obtained a status of the political symbol of the uninterrupted and immortal presence of the ancestors; fourthly, institutionalised political freedoms of the Rus population had inevitably established in the social consciousness and laid grounds for the formation of the Cossacks.

This historic process of the establishment of freedom we determine as its first stage, which is characterised by the patrimonial essence of freedoms, built on the basis of the patriarchal-paternalistic foundations, where obedience in the relationships of power is sort of a natural thing (that is why freedom and obedience are still equal notions). Also, non-political character of freedom - it is only natural, as a "freedom from" burdens, bad luck, poverty, due to which freedom did not receive clear individual definitions, freedom is only collective, family, which does not give rise to the principle of determination of political and social institutions.

We may see another condition of the formation of freedoms in the Cossack times (XVI - XVIII centuries). The freedom here receives real political characteristics, since one of the actual issues of the time was national self-identification (i.e., who are Ukrainians compared to Poles, Turks, Russians). The idea started to form on completely new characteristic - ideas of freedom and state sovereignty. A completely new level of freedoms started to determine the essence of the human himself in connection with the specificity of the economy of Ukrainians (only in the second half of XIX century 1/3 of Ukrainians was under serfdom). The freedom itself received not a mystical, not a utopian definition, but rather a real, actionable form as a fight for freedom, where both the society and the individual were probably the actual subjects of the social and political life in the first time ever in the history.

Bourgeois and democratic revolutions and national liberation movement of the European nations, which were the manifestation of the "embodiment" of the aforementioned manifestation of freedom, provided prospects for restoration and development of Ukrainian nation. However, Ukrainian territories were under the rule of different empire states with different level of development of political culture, law, social morale, education etc. Austrian monarchy of the "educated 
absolutism" and Russian monarchic despotism were unequal in their treatment of the Ukrainian nation, which was already analysed in the context of the dominant empire spirit of the time and uprising of the national consciousness of the nations, which were colonised by the empire states. This means that Ukrainian national genesis and its institutionalised political freedoms were considered only in the tightest connection with the empire spirit of the European geopolitical space and national liberation movements.

Considering the above, we may view the third stage of the establishment of the idea and practice of the formation of political freedoms in the Ukrainian national genesis in the second half of XVIII - XIX centuries, which we could generally view as a stage of romantic freedoms. The specificity if this romantic period is determined, in our opinion, primarily by the specific organic worldview of the thinkers, where the complete picture also contains tradition, history, specific experiencing of the heroic past of the people, as well as poetically, artsy, creatively desired future, as well as a romantic reference to the specific, individually unrepeated being of a human, ethnos, nation, acknowledged historically. We should include a universally harmonised combination of the phenomena "human society - state" into this characteristic, through the principles of social laws, which must have become foundations for formation of legal norms, as well as the whole system of the political institutes and relations in the society, thereby forging substantial grounds for the mere practice of political freedoms, as well as especially sharp, partly involved in the revolutionary vocabulary of the desire for freedoms in the form of national and state independence.

\section{SUMMARY}

In this article the author analyses anthropological and institutional grounds for realisation of political freedom in the context of Ukrainian national genesis. The nature, political and ideological preconditions of the influence of the Cossacks onto the incipience of the Ukrainian identity during the rule of Rzeczpospolita over Ukrainian lands have been analysed. The specificity of the impact of ideas of the Enlightenment on the development and formation of the Ukrainian national genesis during the Austro-Hungarian and Moscow Empires rule over the territory of modern Ukraine has been clarified. The input 
of the Western European and Eastern European civilisations in the development of the anthropology has been substantiated. Principal philosophic and political preconditions of the formation and spreading of the concept of Ukrainian national ideology have been considered. Finally, the author demonstrated principal political and social preconditions of the formation of Ukrainian national genesis during XVII - XIX centuries.

\section{REFERENCES}

1. Бачинський Ю. Економічні підстави самостійності націй. Київ: Смолоскип, 2006. С. 420-421.

2. Блажейовський Д. Берестейська унія та українська історична доля і недоля. T. 1 : Внутрішня вартість медалі. Львів: Каменяр, 1995. 646 с.

3. Булатова Ю. Про поняття філософії історії. Вісник Київського університету. 1996. Вип. 25. С. 3-12.

4. Голобуцький В. Запорозьке козацтво. Київ: Вища школа, 1994. $539 \mathrm{c}$.

5. Грушевський М. Історія України. Київ: Либідь, 1992. $228 \mathrm{c}$.

6. Ефименко А. История украинского народа. Київ: Либідь, $1990.512 \mathrm{c}$.

7. Єфименко О. Історія України та іï народу. Київ : Мистецтво, 1992. $256 \mathrm{c.}$

8. Локк Дж. Два трактата о правлении. Сочинения: в 3 т. Т. 3. / Локк Дж. Москва: Мысль, 1988. 668 с.

9. Полонська-Василенко Н. Історія України: у 2 т. Київ: Либідь, 1995. Т. 1. 640 с. ; Т. 2. 608 с.

10.Попович М. Нарис історії культури України. Київ АртЕк, $1998.728 \mathrm{c}$.

11. Солдатенко В. Революції в історичній долі України. Віче. 1999. № 4. С. 117-130.

12.Уайтхед А. Избранные работы по философии. Москва: Прогресс, 1990. 710 с.

13. Щербак В. Українське козацтво: формування соціального стану. Друга половина XV - середина XVII ст. Київ: КМ Academia, 2000. 300 c. 
14. Яворницький Д. Історія запорізьких козаків: у 3 т. Київ: Наукова думка, 1990-1992. Т. 1.1990. 319 с.; Т. 2.1991. 392 с.; Т. 3. $1992.456 \mathrm{c}$.

15. Яковенко Н. До питання про методологію вивчення історії України. Генеза: Філософія. Історія. Політологія. № 1 (4). 1996. С. 118-124.

16. Яковенко Н. Нарис історії України з найдавніших часів до кінця XVIII ст. Київ: Генеза, 1997. 380 с.

\section{Information about the author: Shypunov H. V.,}

Doctor of Political Sciences, Associate Professor, Department of Theory and History of Political Science, Ivan Franko Lviv National University 1, Universytetska str., Lviv, 79000, Ukraine Prokop M.,

$\mathrm{PhD}$ (Candidate of Political Sciences), Adjunct, Institute of International Relations and Public Policies, Faculty of Law and Social Sciences, Jan Kochanowski University in Kielce, Kielce, Poland 